\title{
COMPARISON OF CHEMOTHERAPY RESPONSE AND ADVERSE EFFECTS OF DOUBLE- PLATINUM PLUS EGFR-TKI VERSUS DOUBLE-PLATINUM ALONE ON NSLCLC PATIENTS WITH DISEASE PROGRESSION AND EGFR-TKI TREATMENT
}

\author{
Laksmi Wulandari' ${ }^{1}$ Edward Pandu Wiriansya ${ }^{2}$ \\ ${ }^{1}$ Department of Pulmonology and Respiratory Medicine, Faculty of Medicine, Universitas Airlangga, Dr. Soetomo \\ Hospital, Surabaya, ${ }^{2}$ Department of Pulmonology Medicine, Faculty of Medicine, Universitas Muslim Indonesia, \\ Ibnu Sina Hospital, Makassar, Indonesia
}

\begin{abstract}
ABSTRAK
EGFR-TKI adalah terapi lini pertama untuk pasien mutan EGFR. Namun, pasien akan mengalami perkembangan penyakit (median PFS 10 - 12 bulan) akibat resistensi. Pilihan pengobatan masih terbatas di negara berkembang untuk kasus semacam ini, sehingga kemoterapi double-platinum adalah pilihan berikutnya. Meskipun studi IMPRESS melaporkan tidak ada perbedaan dalam hal PFS dan OS antara double-platinum dan double-platinum plus EGFR-TKI, beberapa penelitian lokal melaporkan manfaat dari EGFRTKI lanjutan dalam kombinasi dengan kemoterapi double-platinum (treatment beyond progression). Penelitian ini bertujuan untuk membandingkan efek kemoterapi double-platinum dan EGFR-TKI versus double-platinum pada pasien dengan perkembangan NSCLC setelah pengobatan EGFR-TKI. Penelitian ini adalah penelitian deskriptif analitis dengan menggunakan rancangan kohort prospektif, melibatkan 30 pasien dengan perkembangan penyakit setelah perawatan EGFR-TKI yang memenuhi kriteria inklusi di RSUD Dr. Soetomo, Surabaya. Subyek dibagi menjadi dua kelompok: lengan A (double-platinum dan EGFR-TKI) dan lengan B (hanya double-platinum). Subjek kemudian diamati sampai 4 siklus kemoterapi double-platinum. Respon subjektif (berat badan dan kuesioner EQ5D) dianalisis, CT scan dilakukan menggunakan kriteria RECIST, dan efek sampingnya dipantau. Penelitian ini dilakukan sesuai dengan prinsip GCP dan telah menerima sertifikat etika dari komite etika RSUD Dr. Soetomo (No. 08/ Panke.KKE/I/2017). Hasil penelitian menunjukkan bahwa karakteristik subjek antara dua lengan berbeda secara signifikan ( $p=0,05)$. Mutasi EGFR yang paling umum adalah ekson 21 (50\% pada lengan A dan 60\% pada lengan B). Uji kuadrat diuji pada parameter respon subyektif $(E Q 5 D(p=0,483))$. Sampel bebas T2 diuji pada parameter semi subyektif (berat badan $(p=1.00))$. Uji perbandingan pada kedua kelompok setelah siklus 2 dan 4 menunjukkan nilai $p=0,05$. Uji statistik terhadap efek samping antara kedua kelompok menunjukkan nilai p=0,526. Sebagai kesimpulan, penelitian ini menunjukkan tidak ada perbedaan yang signifikan antara double-platinum dan double-platinum plus EGFR-TKI pada pasien yang mengalami perkembangan penyakit setelah pengobatan EGFR-TKI. (FMI 2017;53:276-282)
\end{abstract}

Kata kunci: NSCLC; EGFR-TKI; perkembangan penyakit; double-platinum

\begin{abstract}
EGFR-TKI is the first-line therapy for EGFR-mutant patients. Nevertheless, patients will have disease progression (median PFS 10 12 months) due to resistance. The treatment options are still limited in developing countries for such cases, thus double-platinum chemotherapy is the next option. Although IMPRESS study reported no difference in terms of PFS and OS between double-platinum alone and double-platinum plus EGFR-TKI, several local studies reported benefit of continuing EGFR-TKI in combination with double-platinum chemotherapy (treatment beyond progression). This study aimed to compare chemotherapy effects of doubleplatinum plus EGFR-TKI versus double-platinum alone on patients with NSCLC progression after EGFR-TKI treatment. This was an analytical descriptive study using prospective cohort design, involving 30 patients with disease progression following EGFR-TKI treatment that met inclusion criteria in Dr. Soetomo Hospital. Subjects were divided into two groups: arm A (double-platinum plus EGFR-TKI) and arm B (double-platinum alone). Subjects were observed until 4 cycles of double-platinum chemotherapy. Subjective response (body weight and EQ5D questionnaire) was analyzed, chest CT scans were evaluated using RECIST criteria, and adverse effects were monitored. This study was conducted in accordance with GCP principles and has received ethics certificate from Dr. Soetomo Hospital ethics committee (No. 08/Panke.KKE/I/2017). The results showed that subject characteristics between two arms were insignificantly different $(p=0.05)$. The most common EGFR mutation was exon $21(50 \%$ on arm A and 60\% on arm B). Chi square was tested on subjective response parameter $(E Q 5 D(p=0.483))$. T2 free sample was tested on semi-subjective parameter (body weight $(p=1.00)$ ). Comparison test on both groups after cycle 2 and 4 showed $p$ value $=0.05$. Statistical test on adverse effect between both groups showed $p$ value $=0.526$. As a conclusion, there was no significant difference between double-platinum and double-platinum plus EGFR-TKI on patients who had disease progression following EGFR-TKI treatment. (FMI 2017;53:276-282)
\end{abstract}

Keywords: NSCLC; EGFR-TKI; disease progression; double-platinum

Correspondence: Laksmi Wulandari, Department of Pulmonology and Respiratory Medicine, Faculty of Medicine, Universitas Airlangga, Jalan Prof dr Moestopo 6-8, Surabaya 60286, Indonesia. Email: laksmigts@yahoo.co.id 


\section{INTRODUCTION}

Lung cancer is one of lethal cancers in the world and the number one cause of death among all cases of malignancy. In the United States, lung cancer kills 160,000 people each year. The occurrence of new lung cancer cases in the United States ranks second after breast cancer, which was estimated at 224,390 cases by 2016 or about $13 \%$ of all cancer diagnoses. Deaths occurred in 158,080 by 2016 or about $27 \%$ of all cancer deaths (Murray 2005, American Cancer Society 2016).

The occurrence of lung cancer in Indonesia tends to increase. Data and information center of Ministry of Health Republic Indonesia show that the incidence of lung cancer at Dharmais Cancer Hospital in 2013 ranks third after breast cancer and cervical cancer are 173 cases or $7 \%$ of all cancers and deaths caused lung cancer are 65 cases or $12 \%$ of all deaths caused by cancer (INFODATIN 2015). This incidence is closely related to smoking history, and about $10 \%$ of old smokers will be diagnosed with lung cancer (Murray 2005). The mortality rate in all stages of cancer is only about $16 \%$. Non Small Cell Lung Carcinoma (NSCLC) contributes for about $80 \%-85 \%$. At initial diagnosis, about $70 \%$ of lung cancer have been in advanced stage (stage IIIB/IV), so the choice of therapy is platinum-based chemotherapy (Sun et al 2013, American Cancer Society 2013).

Surgery, radiation therapy, chemotherapy and therapeutic targets are commonly used as therapy in NSCLC patients. Currently, some experts have found chemotherapy with target therapy through tyrosine inhibitor molecules with EGF (epidermal growth factor) receptors. EGF receptors play an important role in erb-B signaling pathways that can increase cancer cell proliferation and tumor invasion, and EGFR (epidermal growth factor receptor) is one of four related structures in the erb-B transmembrane tyrosine kinase family (American Cancer Society 2013).

One type of lung cancer targeted by biologic therapy is adenocarcinoma, which accounts for $40 \%$ of all cases of pulmonary malignancy. In adenocarcinoma, mutations may occur secretly in genes encoding epidermal receptor growth factor (EGFR), Receptors Tirosin Kinase (RTKs) including tumor cell proliferation as well as surviving ones. Two key mutations found in EGFR are L858R, arginine for substituting leucine in exon 21, and deletion exon 19 . These mutations increase the activity of the EGFR kinase, but the interesting thing about this mutation process is the removal of sensitivity to EGFR tyrosine kinase inhibitor (TKIs) (American Cancer Society 2013, Ettinger at al 2015, Lynch et al 2004, Paez 2004, Pao et al 2004).
EGFR-TKI therapy is promising, but there are still obstacles, such as acquired resistance. Most patients treated with TKIs will experience resistance during the associated 10 to 16 months of therapy. This can be associated to resistances that can be complex and heterogeneous. The choice of therapy in cases of resistance is still very limited in some countries. Although IMPRESS studies point out no difference in therapy between single platlet doublets and platinum doublet combined EGFR TKIs, but some local studies have reported benefits for this type of therapy (Sachs \& Bilfinger 2005, Lin et al 2014)

\section{MATERIALS AND METHODS}

This was a randomized cohort prospective study. The population of this study was outpatients with diagnosis of lung cancer in Dr. Soetomo Hospital, Surabaya. The inclusion criteria for this study were patients aged 21 to 70 years of NSCLC at least stage IIIA with positive mutation of EGFR and received EGFR TKI therapy and then became progressive disease, having at least one tumor or measurable lesion, good hematological status ( $\mathrm{Hb}>10 \mathrm{~g} \%$ leukocytes $>4000 / \mathrm{mm} 3$, platelets $>100,000$ ), good liver function (AST and ALT< $<$ normal value), good renal function (creatinine serum $<1,5 \mathrm{x}$ normal value), willing to fill out questionnaires, and following the study (signing informed consent).

The number of research subjects for arm A (doubleplatinum alone) was 15 patients, while for arm B (EGFR TKI with double-platinum) was 15 patients. Patient data used in this study were primary data from history, physical examination, laboratory, CT scan thoracic and questionnaire. The administration of doubleplatinum combined with EGFR-TKI and double-platinum alone were then evaluated for subjective response, semisubjective response, objective response and side effects of chemotherapy. Data were analyzed with statistical test, using Chi-square, Mann-whitney, and free sample $\mathrm{T} 2$ tests.

\section{RESULTS}

The results of the description for the study subject profile is presented in Table 1. Obtained characteristics by sex for arm A, female ratios were higher than for males in both arms. Non-smoker samples were more common in both arms of study subjects, were 10 patients (53.3 $\%)$ in arm A and 8 patients $(80 \%)$ in arm B.

Research sample of age and duration of EGFR TKI therapy have the same variation. Performance score on research subject is generally good with PFS scale 1 
WHO. Histopathologic diagnosis is generally established based on FNAB in both arms, where most of the EGFR mutation results was exon 21. A proportion of $53.3 \%$ were in the platinum doublet combined with EGFR TKI arm and $60 \%$ in the single platinum doublet arm.

In Table 2, there is no significant difference of EQ5D between single platinum doublet and combination both in initial measurement and from cycle I to cycle IV. The subjective response based on EQ5D obtained stable results in both arms. Both arms had $\mathrm{p}$ value in chisquare test of 0.483 . It means that there was no significant difference from both arms to EQ5D. The evaluation result of subjective response in arm $\mathrm{A}$ and arm B is shown in Fig. 1 .

Table 1. Characteristics of research subjects

\begin{tabular}{|c|c|c|c|c|}
\hline \multirow[t]{2}{*}{ Characteristic } & \multicolumn{2}{|c|}{$\begin{array}{c}\text { Arm A } \\
\text { Platinum doublet } \\
\text { combined with } \\
\text { EGFR TKI }\end{array}$} & \multicolumn{2}{|c|}{$\begin{array}{c}\text { Arm B } \\
\text { Single platinum } \\
\text { doublet }\end{array}$} \\
\hline & $\mathrm{N}$ & $\%$ & $\mathrm{~N}$ & $\%$ \\
\hline \multicolumn{5}{|l|}{ Sex } \\
\hline Male & 7 & 46.7 & 5 & 33.3 \\
\hline Female & 8 & 53.3 & 10 & 66.7 \\
\hline \multicolumn{5}{|l|}{ Smoker status } \\
\hline Non-smoker & 8 & 53.3 & 12 & 80 \\
\hline Smoker & 7 & 46.7 & 3 & 20 \\
\hline \multicolumn{5}{|l|}{ WHO } \\
\hline 1 & 12 & 80 & 9 & 60 \\
\hline 2 & 3 & 20 & 6 & 40 \\
\hline \multicolumn{5}{|l|}{ Age (years) } \\
\hline $\begin{array}{l}\text { Mean } \pm \text { Standar Deviation } \\
\text { Therapy duration of EGFR }\end{array}$ & \multicolumn{2}{|c|}{$55.07 \pm 7.778$} & \multicolumn{2}{|c|}{$50.93 \pm 10.025$} \\
\hline Mean \pm Standar Deviation & \multicolumn{2}{|c|}{$12.40 \pm 5.938$} & \multicolumn{2}{|c|}{$9.93 \pm 5.431$} \\
\hline \multicolumn{5}{|l|}{ Sampling method } \\
\hline FNAB & 14 & 93.3 & 15 & 100 \\
\hline Sitology & 1 & 6.7 & 0 & 0 \\
\hline \multicolumn{5}{|l|}{ Mutation of EGFR } \\
\hline Ex 19 & 7 & 46.7 & 6 & 40 \\
\hline Ex 21 & 8 & 53.3 & 9 & 60 \\
\hline \multicolumn{5}{|l|}{ Mutation of Ex 21} \\
\hline L858R & 8 & & 7 & \\
\hline L861Q & 0 & & 2 & \\
\hline
\end{tabular}

Table 2. Descriptive numerical values based on EQ5D in both arms of study subjects

\begin{tabular}{clccc}
\hline \multicolumn{1}{c}{ EQ5D } & $\begin{array}{c}\text { Platinum } \\
\text { Doublet }\end{array}$ & $\mathrm{N}$ & $\begin{array}{c}\text { Median } \\
(\min -\max )\end{array}$ & $\begin{array}{c}\text { P value } \\
\text { Mann-Withney }\end{array}$ \\
\hline Initial & Single & 15 & $6(5-8)$ & 0.865 \\
& Combination & 15 & $6(5-7)$ & \\
Cycle I & Single & 15 & $6(5-8)$ & 0.865 \\
& Combination & 15 & $6(5-7)$ & \\
Cycle II & Single & 15 & $6(5-8)$ & 0.653 \\
& Combination & 15 & $6(6-7)$ & \\
Cycle III & Single & 15 & $6(5-8)$ & 0.272 \\
& Combination & 15 & $6(6-8)$ & \\
Cycle IV & Single & 15 & $6(5-8)$ & 0.272 \\
& Combination & 15 & $6(6-8)$ & \\
\hline
\end{tabular}




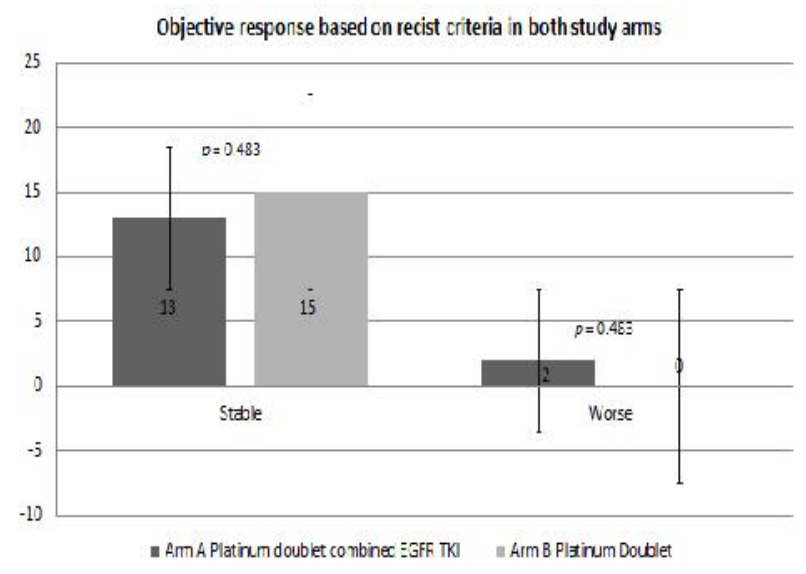

Fig. 1. Subjective response of therapy based on EQ5D in both arms of study subjects.

The descriptive numerical value of the semisubjective response based on the weight in Table 3 shows the result of the free sample T2 test. There was no significant difference in weight between double-platinum alone and combination of both in the initial measurement and from cycle I to cycle IV. The two arms had p value of 1.000 which can be interpreted as no significant difference in both arms. The evaluation result of subjective response in arm A and arm B is shown in Table 4.

The objective response based on result of thoracic CT scan and the contrast with RECIST criteria in cycle II generally showed stable disease results in both arms of study subjects. Similar results were obtained from the objective response of the fourth cycle which was stable disease in both arms. The evaluation result of objective response showed that there was no significant difference in the objective response of cycle II ( $p$ value $=0.424)$ and cycle IV ( $p$ value $=0.638)$ in the two study subjects. The data are shown in Fig. 2 and Fig. 3.

Side effects were evaluated after chemotherapy was given. The results of these evaluations showed alopecia as the highest side effect in the arm A of study subjects. Whereas, in arm B, the most common side effects were nausea/vomiting, while itching was found only in arm B.

Side effects occurred generally in cycle I. Based on statistical data on comparison of ESO of doubleplatinum chemotherapy, there was no significant difference between two arms of study subjects (Table 5). Other side effects of acne, paranocia, thrombocytopenia, impaired liver function and kidney function were not found. Evaluation results of drug side effects and ESO chemotherapy ratio in both study subjects are presented in Fig. 4 and Table 6.

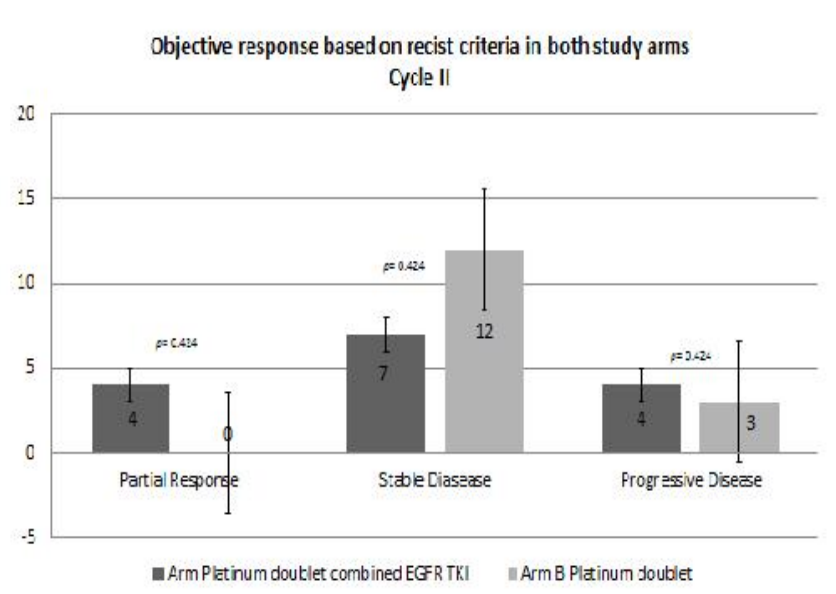

Fig. 2. Objective response based on RECIST criteria in both study arms Cycle II.

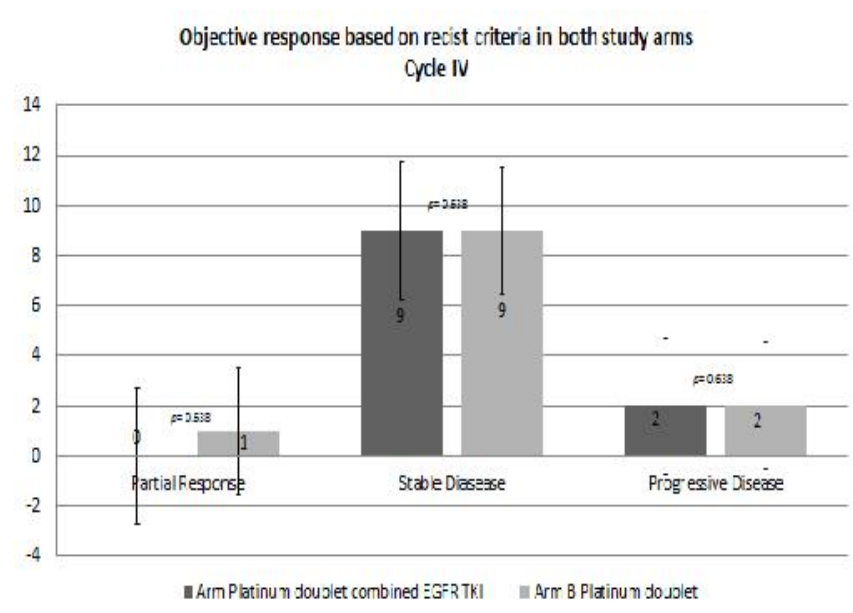

Fig. 3. Objective response based on RECIST criteria in both study arms Cycle IV.

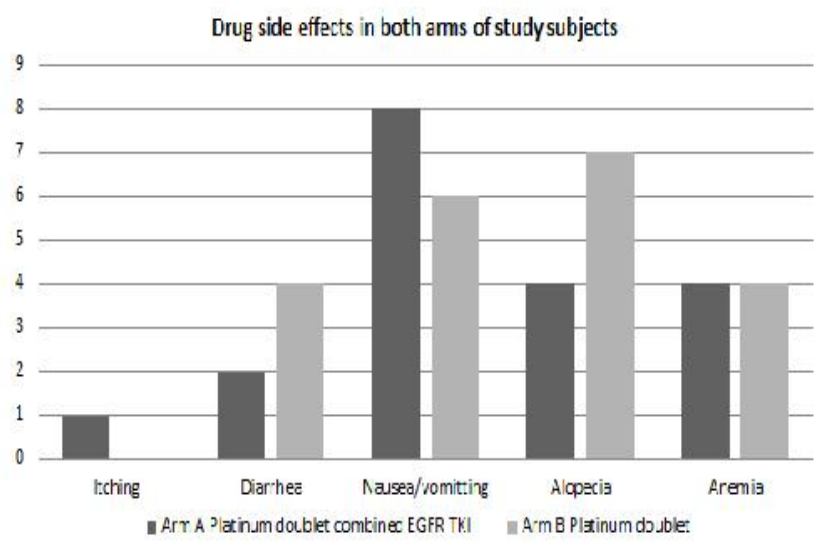

Figure 4. Drug side effects in both arms of study subjects. 
Table 3. Descriptive numerical values based on body weight in both arms of study subjects

\begin{tabular}{clccc}
\hline $\begin{array}{c}\text { Body } \\
\text { weight }\end{array}$ & $\begin{array}{c}\text { Platinum } \\
\text { Doublet }\end{array}$ & $\mathrm{N}$ & $\begin{array}{c}\text { Mean } \pm \text { Standar } \\
\text { Deviation }\end{array}$ & $\begin{array}{c}\text { P value of free } \\
\text { sample T2 test }\end{array}$ \\
\hline Initial & Single & 15 & $47.33 \pm 4.419$ & 0.052 \\
& Combination & 15 & $51.80 \pm 7.282$ & \\
Cycle I & Single & 15 & $47.33 \pm 4.419$ & 0.052 \\
& Combination & 15 & $51.80 \pm 7.282$ & \\
Cycle II & Single & 15 & $47.33 \pm 4.419$ & 0.058 \\
& Combination & 15 & $51.73 \pm 7.401$ & \\
Cycle III & Single & 15 & $47.58 \pm 4.981$ & 0.161 \\
& Combination & 15 & $50.64 \pm 5.085$ & \\
Cycle IV & Single & 15 & $47.67 \pm 5.051$ & 0.175 \\
& Combination & 15 & $50.64 \pm 5.085$ & \\
\hline
\end{tabular}

Table 4. Weight-based therapy response in both arms of study samples

\begin{tabular}{|c|c|c|c|c|c|}
\hline \multirow[t]{2}{*}{$\begin{array}{c}\text { Body } \\
\text { weight }\end{array}$} & \multicolumn{2}{|c|}{$\begin{array}{c}\text { Arm A } \\
\text { Platinum doublet } \\
\text { combined EGFR } \\
\text { TKI }\end{array}$} & \multicolumn{2}{|c|}{$\begin{array}{c}\text { Arm B } \\
\text { Platinum Doublet }\end{array}$} & \multirow[t]{2}{*}{$\begin{array}{c}\mathrm{P} \text { value } \\
\text { Chi-square }\end{array}$} \\
\hline & $\mathrm{N}$ & $\%$ & $\mathrm{~N}$ & $\%$ & \\
\hline Increased & 1 & 6.7 & 1 & 6.7 & 1.000 \\
\hline Decreased & 1 & 6.7 & 0 & 0 & \\
\hline Stable & 13 & 86.7 & 14 & 93.3 & \\
\hline Total & 15 & 100 & 15 & 100 & \\
\hline
\end{tabular}

Table 5. Early onset of drug side effects in both arms of study subjects

\begin{tabular}{ccccc}
\hline \multirow{2}{*}{ Cycle } & \multicolumn{2}{c}{$\begin{array}{c}\text { Arm A } \\
\text { Platinum doublet } \\
\text { combined EGFR TKI }\end{array}$} & \multicolumn{2}{c}{$\begin{array}{c}\text { Arm B } \\
\text { Platinum doublet }\end{array}$} \\
\cline { 2 - 5 } & $\mathrm{N}$ & $\%$ & $\mathrm{~N}$ & $\%$ \\
\hline I & 7 & 58.3 & 12 & 80 \\
II & 5 & 41.7 & 3 & 20 \\
\hline Total & 12 & 100 & 15 & 100 \\
\hline
\end{tabular}

Table 6. Comparison of drug side effects in both arms of study subjects

\begin{tabular}{|c|c|c|c|c|c|c|}
\hline \multirow[t]{2}{*}{$\begin{array}{l}\text { Total of } \\
\text { drug side } \\
\text { effects }\end{array}$} & \multicolumn{2}{|c|}{$\begin{array}{c}\text { Arm A } \\
\text { Platinum doublet } \\
\text { combined EGFR TKI }\end{array}$} & \multicolumn{2}{|c|}{$\begin{array}{c}\text { Arm B } \\
\text { Platinum doublet }\end{array}$} & \multicolumn{2}{|c|}{ Total } \\
\hline & $\mathrm{N}$ & $\%$ & $\mathrm{~N}$ & $\%$ & $\mathrm{~N}$ & $\%$ \\
\hline 0 & 2 & 13.3 & 0 & 0 & 2 & 6.7 \\
\hline 1 & 8 & 53.3 & 9 & 60 & 17 & 56.7 \\
\hline 2 & 4 & 26.7 & 6 & 40 & 10 & 33.3 \\
\hline 3 & 1 & 6.7 & 0 & 0 & 1 & 3.3 \\
\hline Total & 15 & 100 & 15 & 100 & 30 & 100 \\
\hline \multicolumn{7}{|c|}{$\mathrm{P}$ value Mann Whitney test $=0.526$} \\
\hline
\end{tabular}

\section{DISCUSSION}

Based on the descriptive results for the sex profile, the study subjects were mostly female in the two study subjects. Based on age, the subjects were generally aged over 50 years with the same age variation in both arms.
This is in accordance with IPASS and WJTOG3405 research in which the study subjects on IPASS were females and the age generally ranged above 50 years. The subjects of this study were NSCLC patients who had positive EGFR mutations and dominated by nonsmoker patients. It is in accordance with IPASS re- 
search which used more non-smoker patients. This is also not different from the previous study which stated that non-smoker patient arms tend to have positive EGFR mutations.

All subjects were patients of lung adenocarcinoma with positive EGFR mutation and received gefitinib therapy prior to progressive disease. The largest mutation of the two study arms was exon 21, wherein the L858R mutation pathway was dominated by exon 21 in both arms. Exon 19 has stronger bonds with TKI (gefitinib) than exon 21 , leading to more dominant exon 21 pro-gressive diseases. The meta-analysis study by Zhang et al (2014) from 13 studies found that exon 19 had progression free survival longer than exon 21 in the administration of gefitinib as first line. Three hypo-theses had been developed today that exon 19 has greater affinity for EGF receptors than exon 21 . T790M, as a secondary mutation that is resistant to TKI, more commonly occurs with exon $21 \mathrm{~L} 858 \mathrm{R}$, which is a point mutation with the largest proportion of exon 21 and exon 18 (G719S) which more often appear along with exon 21 (L858R) (Zhang et al 2014).

The duration of EGFR therapy (initial treatment to progressive disease) ranges over 9 months. The emerging problem is that most patients with an initial response to gefitinib or erlotinib are able to suppress tumor growth and most of it becomes resistant in 6 months to 12 months, called "acquired resistance" (Soria et al 2015). The tumor cells may also mutate again as a defense effect against the anticancer therapy given, i.e. secondary mutations in T790M. However, there are many other causes, including MET amplification or PI3K mutation and transformation into small cell lung cancer. The existence of this mutation causes secondary resistance, so tumor cells become resistant to TKI. Tumor cells that are resistant to TKI will give different results on the evaluation of their clinical response (American Thoracic Society/European Respiratory Society 1997).

The subjective response is known from a subjective assessment of the patient's or clinical health status using standardized scoring issued by EuroQol which is the EQ5D-3L. This assessment includes mobility, the ability to perform daily physical activity, the ability to do work, pain, discomfort, and depression or anxiety. The EQ5D score is evaluated per cycle. The results of the evaluation showed stable conditions in both arms of study subjects and there was no significant difference from the two study arms. The same results were also obtained from the semisubjective response of weight evaluation. The weight of the study subjects tended to be stable and there was no significant difference from the two study arms. An IMPRESS study conducted by
Soria et al (2015) showed no significant improvement in life expectancy with continuation of gefitinib in addition to double-platinum combination with double-platinum chemotherapy in patients with resistance or progressive disease.

Objective responses were assessed from RECIST criteria based on thoracic CT scan with contrast. This objective response was assessed 2 weeks after second and fourth cycle chemotherapy in both arms. The results in arm A showed stable disease in cycle II and cycle IV. The same results were obtained in arm B. A study conducted by Soria et al (2015) also showed no change in the objective response (stable disease) in the study subjects with EGFR TKI resistance or progressive disease. The possibility of the absence of therapeutic response in both arms of their study may be caused by secondary mutation. This resistance mechanism was complex and heterogeneous. The most common cause of TKI EGFR resistance is mutation in EGFR gene which is ex-20-T790M mutation. However, there are many other causes other than the 20-T790M exon mutation, which is MET or PI3K mutation, that may transform into small cell lung cancer (Lin et al 2014, Zhang et al 2014)

Side effects were assessed after chemotherapy each cycle. Therapeutic side effects generally appeared in the first cycle. Common effects in both arms were gastrointestinal side effects of nausea/vomiting (40\% in arm B and $53.3 \%$ in arm A) and diarrhea $(26.7 \%$ in arm B and $13.3 \%$ in arm A). The percentage of nausea/ vomiting was quite high in this study, according to some previous studies that showed frequent nausea/vomiting in chemotherapy. This chemotherapy can activate the direct chemoreceptor trigger of the vomiting center. In addition, these chemotherapy drugs can stimulate vomiting by damaging gastrointestinal cells. Another symptom that can happen in the gastrointestinal system is a change in the composition of normal flora of the intestine resulting in impaired absorption, changes in mortality and damage to intestinal crypts. The disorder can cause diarrhea (Griffin et al 1996).

Alopecia was one of the most common side effects in both treatment arms. It occurred as much as $46.7 \%$ in arm A and $26.7 \%$ in arm B. Hair loss caused by chemotherapy drugs suppresses the mitotic process of hair matrix. Chemotherapy drugs do not damage the hair follicle stem cells because the cell division is relatively slow. This causes the side effects of alopecia will be lost 3 months to 6 months post chemotherapy and hair can grow back (Griffin et al 1996). Other side effects is anemia ( $26.7 \%$ in both arms). Anemia occurs because of bone marrow suppression, which is usually occur in 1 week post-chemotherapy. Itching was only 
found in arm B at $6.7 \%$. This itching reaction is a side effect from EGFR TKI which is an on-target side effect of pharmacology with frequencies varying from $45 \%$ to $100 \%$ in some clinical studies. Statistical data showed no significant difference in side effects between the two study arms $(\mathrm{p}=0.526)$. This is consistent with previous study by Lin et al (2014) which obtained no difference in the side effects between double-platinum combined with EGFR-TKI arm and double-platinum arm, in contrast to the Soria et al's (2015) study whose the side effects were commonly found in double-platinum combined with EGFR TKI arm than that in double-platinum arm (Bethune et al 2010, American Thoracic Society/European Respiratory Society 1997)

The limitation of this study is that this study did not assess the progression of free survivor and overall survival of the study subjects. Waiting lists for schedule of CT scan thoracic were dense, leading to an overdue examination of the objective response.

\section{CONCLUSION}

There was no significant differences in terms of subjective, semisubjective, objective responses. Based on therapeutic side-effects, the best treatment option is double-platinum alone.

\section{REFERENCES}

American Cancer Society (2016). Cancer facts \& figures 2016. Atlanta: American Cancer Society, 1-64

American Cancer Society (2013). What is non-small cell lung cancer? Atlanta: American Cancer Society, $1-82$.

American Thoracic Society/European Respiratory Society (1997). Pretreatment evaluation of non-small-cell lung cancer. Am J Respir Crit Care Med 156, 320-332

Bethune G, Bethune D, Ridgway N, Xu Z (2010). Epidermal growth factor receptor (EGFR) in lung cancer: an overview and update. J Thorac Dis 2, 48-51

Ettinger DS, Wood DE, Akerley W, et al (2015). Nonsmall cell lung cancer version 3. National Comprehensive Cancer Network Clinical Practice Guideline in Oncology
Griffin AM, Butow PN, Coates AS, Childs AM, Ellis PM, Dunn SM (1996). Patient perception of the side effects of cancer chemotherapy. Annals of Oncology 7, 189-95

INFODATIN (2015). Stop kanker. Pusat Data dan Informasi Kementerian Kesehatan RI

Lin Y, Wang X, Jin H (2014). Review article; EGFR TKI resistance patients: mechanism and strategies. Am J Cancer Res 4, 411-35

Lynch TJ, Bell DW, Sordella R, et al (2004). Activating mutations in the epidermal growth factor recep $\neg$ tor underlying responsiveness of non-small- cell lung cancer to gefitinib. N Engl J Med 350, 2129-2139

Mok TS, Wu YL, Thongprasert S, et al (2009). Gefitinib or carboplatin-paclitaxel in pulmonary adenocarcinoma. N Engl J Med 36, 947-57

Murray (2005). Bronchogenic carcinoma. In: Mason RJ ed. Murray and Nadel's Textbook Of Respiratory Medicine. 4th ed. Philadelphia, Elsevier Saunders, p 1357-82

Paez J (2004). EGFR mutations in lung cancer: corelation with clinical response to gefitinib therapy. Science 304, 1497-1500

Pao W, Miller V, Zakowski M, et al (2004). EGF receptor gene mutations are common in lung cancers from 'never smokers' and are associated with sensitivity of tumors to gefitinib and erlotinib. Proc Natl Acad Sci 101, 13306-13311

Sachs S, Bilfinger VT (2005). The impact of positronemosion tomography on clinical decision making in university-based multidisciplinary lung cancer practice. Chest 128, 698-708

Soria JC, Wu Y, Nakagawa K, et al (2015). Gefitinib plus chemotherapy versus placebo plus chemotherapy in EGFR-mutation-positive non-small-cell lung cancer after progression on first-line gefitinib (IMPRESS): a phase 3 randomised trial. The Lancet Oncology 16, 990-998

Sun J, Ohashi K, Pao W (2013). Characterizing acquired resistance to egfr tyrosine kinase inhibitors in an EGFR mutant lung adenocarcinoma cell line. Engineering and Natural sciences 9, 1-7

Zhang Y, Sheng J, Kang S (2014). Patients with exon 19 deletion were associated with longer progressionfree survival compared to those with L858R mutation after first-line EGFR-TKIs for advanced non-small cell lung cancer: a metaanalysis. Plos one 9, 1-9 